\title{
IMPLEMENTASI PENDIDIKAN KARAKTER PADA KEGIATAN PEMBELAJARAN BAHASA INGGRIS DI SMKN 1 KANDANGAN KALIMANTAN SELATAN
}

\author{
Arin Ika Puspitaningsih ${ }^{1)}$, Bambang Sugeng ${ }^{2)}$ \\ SMK Negeri 2 Kandangan Kalimantan Selatan ${ }^{1)}$, Universitas Negeri Yogyakarta ${ }^{2)}$ \\ arinikapuspitaningsih@yahoo.co.id ${ }^{1)},{ }^{2)}$
}

\begin{abstract}
Abstrak
Penelitian ini bertujuan untuk memberikan informasi tentang implementasi pendidikan karakter pada kegiatan pembelajaran Bahasa Inggris yang telah dilaksanakan oleh guru. Penelitian ini merupakan penelitian deskriptif kualitatif. Penelitian ini dilaksanakan di SMKN 1 Kandangan, Kalimantan Selatan. Desain penelitian yang digunakan adalah studi kasus. Subjek penelitian ini adalah tiga orang guru mata pelajaran Bahasa Inggris dan enam orang siswa. Objek penelitian ini adalah proses kegiatan pembelajaran Bahasa Inggris yang terdiri atas aktivitas verbal dan nonverbal. Teknik pengumpulan data yang digunakan adalah pengamatan dan wawancara. Instrumen pengumpulan data terdiri atas pedoman pengamatan dan pedoman wawancara. Analisis data dilakukan secara deskriptif dengan menggunakan teknik analisis data model Miles and Huberman. Tahap analisis data tersebut mencakup data reduction, data display, dan conclusion drawing/verification. Hasil penelitian menunjukkan bahwa guru telah mengimplementasikan 10 nilai karakter pada kegiatan pembelajaran Bahasa Inggris. Guru di SMKN 1 Kandangan telah mengimplementasikan 10 nilai karakter pada kegiatan pembelajaran Bahasa Inggris sebagai pelaksanaan dari Silabus mata pelajaran. Nilai-nilai karakter tersebut adalah religiusitas, toleransi, kedisiplinan, kerja keras, kemandirian, demokrasi, kekomunikatifan, kedamaian, kegemaran membaca, dan kekreatifan. Implementasi nilai-nilai karakter tersebut tercermin pada kegiatan pembelajaran Bahasa Inggris secara keseluruhan, yaitu kegiatan awal, inti, dan penutup pembelajaran.
\end{abstract}

Kata kunci: pendidikan karakter, pembelajaran Bahasa Inggris

\begin{abstract}
This study aims at giving information about the implementation of character education in English teaching and learning activities conducted by teachers. This study was descriptive qualitative, conducted at SMKN 1 Kandangan, South Kalimantan. The design of this study was a case-study. The subjects of this study were three English teachers and six students of SMKN 1 Kandangan. The objects were the English teaching and learning activities that consisted of verbal and nonverbal activities. The techniques for collecting the data were observation and interview. The instruments of the data collection were observation sheets and interview guides. The data were analyzed using the descriptive analysis technique applying the Miles and Huberman model. The activities of data analysis were data reduction, data display, and conclusion drawing/verification. The results of the study show that teachers have implemented 10 character values in the English teaching and learning activities. The teachers of SMKN 1 Kandangan have implemented 10 character values in the English teaching and learning activities as the implementation of the syllabus. The character values implemented are religiousity, tolerance, discipline, perseverance, independence, democracy, communicativeness, peace, having good habits in reading, and creativeness. The implementation of those character values integrated in the English teaching and learning activities as a whole procedure, which are preteaching, while-teaching, and post-teaching.
\end{abstract}

Keywords: character education, English teaching learning activity 


\section{PENDAHULUAN}

Undang-Undang Sistem Pendidikan Nasional Nomor 20 Tahun 2003 Pasal 1 yang menyatakan bahwa pendidikan adalah usaha sadar dan terencana untuk mewujudkan suasana belajar dan proses pembelajaran agar peserta didik secara aktif mengembangkan potensi dirinya untuk memiliki kekuatan spiritual keagamaan, pengendalian diri, kepribadian, kecerdasan, akhlak mulia, serta keterampilan yang diperlukan dirinya, masyarakat, bangsa dan negara. Lebih lanjut disebutkan dalam Undang-Undang Nomor 20 Tahun 2003 tentang Sistem Pendidikan Pasal 3 bahwa pendidikan nasional berfungsi mengembangkan kemampuan dan membentuk watak serta peradaban bangsa yang bermartabat dalam rangka mencerdaskan kehidupan bangsa, bertujuan untuk berkembangnya potensi peserta didik agar menjadi manusia yang beriman dan bertakwa kepada Tuhan Yang Maha Esa, berakhlak mulia, sehat, berilmu, cakap, kreatif, mandiri, dan menjadi warga negara yang demokratis serta bertanggung jawab.

Berdasarkan kedua ketentuan yang disebutkan dalam Undang-Undang tersebut, Anwas (2010, p.257) mengemukakan bahwa pendidikan tidak sekedar membentuk manusia yang cerdas saja, akan tetapi membentuk manusia yang utuh memiliki kepribadian dan akhlak mulia. Hal ini sejalan dengan pendapat Benninga, et al (2003, p.19) dalam sebuah situs yang menyatakan "..., the purpose of childhood education has been to cultivate both the moral character and the intellect of youth". Peserta didik diharapkan tidak hanya memiliki kualitas akademik atau intelektual yang baik tetapi juga memiliki kepribadian yang baik serta berakhlak mulia. Dengan kata lain, fungsi sekolah adalah menyiapkan peserta didik untuk hidup dalam masyarakat melalui pembelajaran keahlian dasar, nilai-nilai dan norma-norma budaya, dan aturan-aturan moral seperti yang dikemukakan oleh Alaqehband (Alavi \& Rahimipoor, 2010, p.429).

Pembangunan dan pendidikan karakter merupakan suatu keharusan karena pendidikan tidak hanya menjadikan peserta didik menjadi cerdas tetapi juga mempunyai budi pekerti dan sopan santun, sehingga keberadaannya sebagai anggota masyarakat menjadi bermakna baik bagi dirinya maupun orang lain seperti yang dikemukakan oleh Judiani (2010, p.281). Selain itu, pendidikan karakter yang diterapkan di sekolahsekolah tidak diajarkan dalam mata pelajaran khusus. Akan tetapi, pendidikan karakter dilak- sanakan melalui keseharian pembelajaran yang sudah berjalan di sekolah (Judiani, 2010, p.281). Oleh karena itu, pendidikan karakter dalam kegiatan belajar mengajar di kelas dilaksanakan dengan menggunakan pendekatan terintegrasi dalam semua mata pelajaran, (Pemerintah Republik Indonesia, 2010, p.32).

Pembelajaran Bahasa Inggris di SMK sebagai mata pelajaran adaptif adalah salah satu mata pelajaran yang diharapkan mengimplementasikan nilai karakter yang termuat dalam silabus. Banyak faktor yang mempengaruhi keberhasilan pembelajaran Bahasa Inggris dalam kelas; salah satunya adalah faktor guru sebagai salah satu sumber belajar dalam menyampaikan informasi kepada peserta didik. Peran guru sangat penting dalam membantu peserta didik selama proses kegiatan pembelajaran agar dapat memaksimalkan pencapaian tujuan pembelajaran Bahasa Inggris. Kenyataan yang ada di lapangan guru kurang memperhatikan perannya dalam membantu peserta didik lebih maksimal menyerap semua informasi yang diberikan karena selama ini peran guru hanya sebatas bagaimana menyampaikan secara tuntas semua materi yang terdapat dalam silabus tanpa memperhatikan kebutuhan peserta didik akan peran guru yang sesungguhnya sesuai harapan peserta didik. Dengan kata lain, guru diharapkan mempunyai peranan dalam mengimplementasikan silabus yang memuat nilai karakter ke dalam materi pembelajaran Bahasa Inggris selain menyampaikannya untuk memenuhi tujuan akademis. Hal ini sejalan dengan pendapat Beyer (Marsh, 2010, p.273) yang menyatakan "teachers are moral agents who transmit values overtly or covertly. ...". Guru adalah agen moral yang menularkan nilai-nilai secara langsung dan tidak langsung. Jadi, guru diharapkan dapat menularkan nilai-nilai moral yang baik kepada siswa di samping menyampaikan informasi secara akademik. Pada kenyataannya, silabus mata pelajaran Bahasa Inggris di SMKN 1 Kandangan telah memuat nilai karakter yang harus diimplementasikan dalam pencapaian kompetensi tertentu. Oleh karena itu, implementasi pendidikan karakter yang dilaksanakan oleh guru selama kegiatan pembelajaran Bahasa Inggris sangat diharapkan sehingga pencapaian nilai karakter tersebut dapat tercapai dengan maksimal disamping guru harus menyampaikan materi pembelajaran secara akademis.

Konsep yang melandasi penelitian ini adalah pendidikan karakter. Gray (2009, p.58) menyatakan "Character education is a way to 
help prevent the side effects of unethical behavior". Dengan kata lain, pendidikan karakter adalah cara yang digunakan untuk membantu dalam pencegahan efek samping dari kebiasaan yang tidak sesuai dengan etika. Anne Lockwood (Arthur, 2008, p.90) menyebutkan bahwa pendidikan karakter diartikan sebagai semua program sekolah-institut yang didesain dengan kerja sama dengan komunitas institusi lainnya, untuk membentuk secara langsung dan sistematis perilaku dari peserta didik dengan mempengaruhi secara eksplisit nilai non-relativistik secara langsung yang diyakini untuk menghasilkan perilaku yang diharapkan. Selain itu, Haryanto (2011, p.17) mengemukakan bahwa pendidikan karakter adalah upaya yang terencana untuk menjadikan peserta didik mengenal, peduli dan menginternalisasi nilai-nilai sehingga peserta didik berperilaku sebagai insan kamil. Hal ini sejalan dengan pendapat Lickona (1991, p.51) yang menyatakan bahwa pendidikan karakter yang baik harus melibatkan bukan hanya aspek "pengetahuan yang baik" (moral knowing), tetapi juga "merasakan dengan baik" atau "loving the good" (moral feeling), dan "perilaku yang baik" (moral action). Pendapat Lickona tersebut juga dikemukakan dalam desain induk pendidikan karakter (Kementerian Pendidikan Nasional, 2010, p.11).

\section{METODE PENELITIAN}

Penelitian ini adalah penelitian deskriptif kualitatif dengan desain studi kasus. Moleong (2011, p. 6) mengemukakan bahwa penelitian kualitatif adalah penelitian yang bermaksud untuk memahami fenomena tentang apa yang dialami oleh subjek penelitian. Fenomena yang dimaksud misalnya perilaku, persepsi, motivasi, tindakan, dll., secara holistik, dan dengan cara deskripsi dalam bentuk kata-kata dan bahasa, pada suatu konteks khusus yang alamiah dan dengan memanfaatkan berbagai metode alamiah.

Subjek penelitian ini adalah tiga orang guru mata pelajaran Bahasa Inggris di SMKN 1 Kandangan yang menerapkan pendidikan karakter pada kegiatan pembelajaran dan enam orang siswa. Objek penelitian ini adalah proses kegiatan pembelajaran Bahasa Inggris. Pendidikan karakter yang diimplementasikan pada kegiatan pembelajaran Bahasa Inggris berupa aktivitas verbal dan nonverbal. Penelitian ini menggunakan dua teknik pengumpulan data, yaitu melalui pengamatan dan wawancara.

\section{HASIL-HASIL PEMBAHASAN}

Berikut disajikan berbagai temuan dari 10 nilai karakter yang diimplementasikan oleh guru pada kegiatan pembelajaran Bahasa Inggris di sekolah. Temuan-temuan tersebut didapatkan melalui pengamatan dan wawancara selama proses pengambilan data di lapangan.

\section{Religiusitas}

Implementasi nilai karakter religiusitas dilakukan dengan melakukan doa sebelum dan sesudah selesai pembelajaran. Guru mengajak siswa berdoa pada saat memulai pembelajaran pada jam pertama saja. Guru melakukan hal ini karena menganggap jam pertama sebagai awal rangkaian kegiatan pembelajaran secara keseluruhan. Informasi mengenai kegiatan berdoa di awal pembelajaran dapat ditemukan pada data berikut.

Kira-kira 10 menit berlalu, kemudian $\mathrm{O} 2$ memberikan isyarat bagi siswa untuk berhenti membaca dan memberikan instruksi untuk berdoa sebelum memulai pembelajaran.

O2 : "Okay... before beginning the lesson... let's we pray together. We pray to Allah in order to ask His bless... our lesson runs well... and our knowledge will be useful for us in the future. Amin." (masih duduk di kursi guru). "Come on, Zainal. Lead your friends to pray." (sambil memandang siswa yang dipanggilnya Zainal)

S : "Yes, ma'am" (siswa yang dipanggil Zainal menjawab instruksi guru). "Stay on your seat. Before beginning the lesson, let's pray together."

Terdengar salah seorang siswa memimpin doa yang dibacakan secara bersama-sama oleh seluruh siswa dengan suara keras. (Catatan lapangan 4.XII PM2.20.03.12.01)

Dalam kutipan tersebut, guru mengajak siswa untuk berdoa dengan menggunakan Bahasa Inggris. Penggunaan kata-kata "pray", "bless", Allah, dan Amin menunjukkan bahwa guru telah memasukkan aspek-aspek religiusitas dalam kegiatan pembelajarannya.

Kemudian, guru mengajak siswa untuk berdoa sesudah selesai pembelajaran pada jam terakhir saja. Guru melakukan hal ini karena menganggap jam terakhir sebagai akhir dari keseluruhan rangkaian kegiatan pembelajaran. 
Informasi mengenai kegiatan berdoa di akhir pembelajaran dapat ditemukan pada data berikut.

Bel tanda pelajaran terakhir telah berakhir tidak terdengar karena listrik padam tetapi waktu sudah menunjukkan pukul 14.00 WITA.

O2 : "Okay, close your book. Because of the time is over. Let's we pray together before going home. We pray to say thank you to Allah that our lesson is over and it runs well". (memberikan instruksi tanda jam pelajaran berakhir) "selesaikan dulu membereskan buku dan peralatan kalian, after that... we pray.... Okay. Who's the captain of the class? Please lead your friends to pray".

Tak lama kemudian terdengar suara seorang siswa memimpin doa yang dibacakan secara bersama-sama oleh seluruh siswa dengan suara yang keras. Berakhirlah pembelajaran pada hari itu.

(Catatan lapangan 5.XII AK2.20.03.12.01)

Dalam kutipan tersebut, guru mengajak siswa untuk berdoa dengan menggunakan Bahasa Inggris. Penggunaan kata-kata "pray", dan "thank you to Allah" menunjukkan bahwa guru telah memasukkan aspek-aspek religiusitas dalam kegiatan pembelajarannya.

Selain itu, guru memberikan tugas pekerjaan rumah kepada siswa. Tugas pekerjaan rumah tersebut mencerminkan nilai karakter religiusitas. Hal ini dapat dilihat pada data berikut.

O2 : "Okay, I will give you a home work. Try to make a short story. At home, please tell me what you do in the mosque or musholla near your house. I want you to write it in three paragraphs."

S : "Menulisnya dimana bu? Di kertas atau di buku latihan?" (salah seorang siswa yang duduk di depan bertanya)

O2 : "Tulis di kertas haja (saja). Submit your home work on my desk tomorrow."

S : "Iya, bu..." (menjawab serentak). ... (Catatan lapangan 5.XII AK2.20.03.12.01)

Kutipan tersebut menunjukkan bahwa guru telah mengintegrasikan nilai karakter religiusitas dalam pembelajaran. Hal ini tercermin pada substansi tugas yang meminta siswa untuk membuat karangan yang berhubungan dengan pengalaman religiusitas siswa. Dalam kutipan di atas, guru meminta siswa untuk membuat cerita pendek tentang aktivitas yang dilakukan oleh siswa di masjid atau mushola dekat rumah siswa.

\section{Toleransi}

Nilai karakter toleransi tercermin dalam materi pembelajaran yang diberikan guru kepada siswa. Kegiatan ini dapat dilihat pada data berikut.

O2 memberikan teks bacaan kepada siswa. Teks tersebut tentang origins and nationalities. $\mathrm{O} 2$ membagikan teks tersebut kepada siswa, satu teks untuk dua orang siswa.

Teks yang diberikan oleh $\mathrm{O} 2$ adalah:

Read the text below.

Good afternoon, fellows. May I introduce myself? My name is Rafael Romero. Just call me Rafa. I was born in Mexico, but my parents moved to the USA when I was young, so I'm an American. I speak both English and Spanish. I come to Indonesia to learn about the culture because I like dancing traditional dances. I dream to be a professional dancer one day. I live in Bantul, a small town southward Yogyakarta. I'm glad to know you all and hope that I can get help from you especially in speaking Indonesian. Thank you.

...

O2 : "Perhatikan ya...ibu punya text. Please, read the passage. Come on, Siti ...read it for us". (menatap siswi yang dipanggil namanya)

S : "Iya bu." (kemudian membacakan teks yang diberikan oleh $\mathrm{O} 2$ )

O2 : "Itu tentang apa ya? What is it tell about?"

S : "Bekisah (bercerita) tentang anu ... asal seseorang bu ae" (seorang siswi menjawab pertanyaan $\mathrm{O} 2$ )

$\mathrm{O} 2$ : "Ya... this text tells about origin and nationality ya. What's the lesson that we can learn from this text?"

$\mathrm{S}$ : "Ya tentang asal usul bu ae" (diikuti tawa siswa lain)

O2 : "Iya....asal usul. Ini tentang apa toleransi ya. We have to respect other people no matter what they are. Kita tidak boleh membeda-bedakan teman 
ya. Wherever He or She comes from... their religion, their social status or whatever it is. We have to remember that We are the same level according to Allah. Mengerti ya?"

$$
\text { S : "Iya bu..." (serempak) }
$$

(Catatan lapangan 6.X AK1.21.03.12.01)

Dalam kutipan tersebut, guru memberikan teks tentang origins and nationalities sebagai bahan ajar yang memasukkan aspek karakter toleransi. Guru memberikan penjelasan bahwa teks tersebut mengandung makna yang tersirat bahwa manusia harus hidup bertoleransi dengan manusia yang lain. Guru memberikan penjelasan dengan menggunakan kalimat "Iya... asal usul. Ini tentang toleransi ya. We have to respect other people no matter what they are. Kita tidak boleh membeda-bedakan teman ya. Wherever He or She comes from... their religion, their social status or whatever it is. We have to remember that we are the same level according to Allah. Mengerti ya?" menunjukkan bahwa guru memasukkan aspek-aspek toleransi dalam materi pembelajarannya.

\section{Kedisiplinan}

Guru memberikan materi pembelajaran yang mencerminkan nilai karakter penggunaan waktu secara efektif sebagai bagian dari kedisiplinan. Materi tersebut dapat dilihat pada data berikut.

O2 memberikan teks pendek kepada siswa. Read the text carefully.

Rahardian is a grade one student in a vocational school in his town. He has not got a lesson schedule for one semester. He has got a temporary schedule for one week. Here is his schedule.

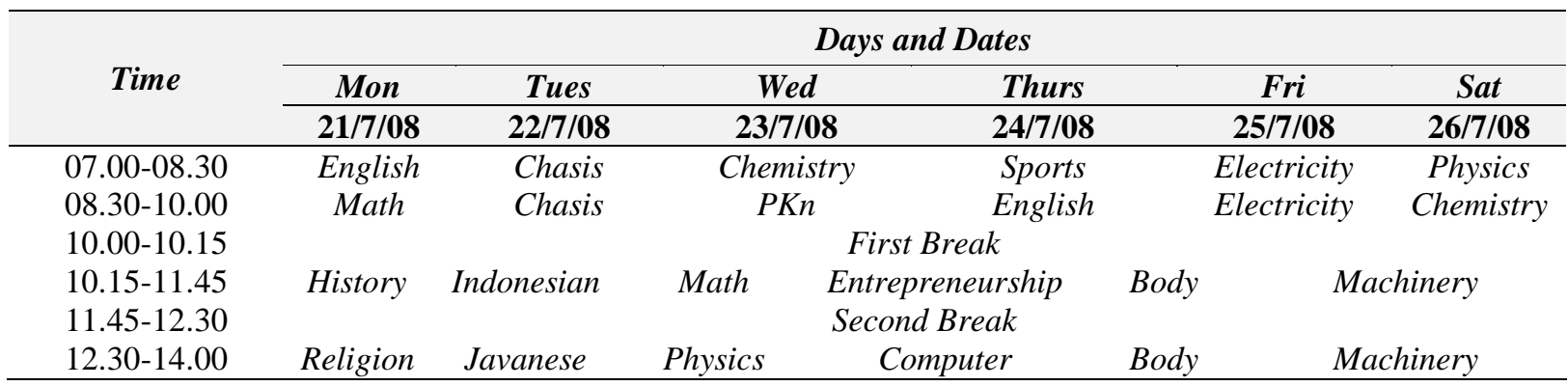

Kemudian, siswa terlihat membaca teks yang diberikan O2. Beberapa saat kemudian terdengar $\mathrm{O} 2$ mulai membahas teks yang diberikan.

O2 : "Bisa dilihat di situ ya, jadwal pelajaran milik Rahardian selama satu minggu." (sambil membaca kertas yang dibawanya)

S : "Iya bu..." (serempak menjawab)

O2 : "Nah, kalau sudah ada jadwal pelajaran harusnya apa?"

S : "Sudah tahu jadwalnya bu..." (salah satu siswa menjawab)

O2 : "Iya. We have to obey the schedule. We have to come to the class on time. We have to bring the book according to the schedule. We have to follow the activities according to the schedule, we have to obey the school's rules, right?." (sambil memandang seluruh siswa)

S : "Iya bu. Harus patuh bu ae"
$\mathrm{O} 2$ : "So...it means that... we have to ... kita harus apa?"

S : "Mematuhi waktu bu, harus sesuai dengan jadwal. Kada (tidak) boleh lambat datang bu ae" (siswi di belakang menyahut)

O2 : "Berarti apa? Kita harus disiplin ya"

S : "Iya bu..." (serempak) (Catatan lapangan 12.X AK 1.28.03.12.02)

Dalam kutipan tersebut, guru memasukkan aspek kedisplinan dalam hal penggunaan waktu dengan memberikan teks pendek tentang schedule kepada siswa. Penggunaan kalimat penjelasan "Iya. We have to obey the schedule. We have to come to the class on time. We have to bring the book according to the schedule. We have to follow the activities according to the schedule, we have to obey the school's rules, right?" menunjukkan bahwa guru memasukkan aspek-aspek kedisiplinan dalam hal penggunaan waktu ke dalam materi pembelajaran. 


\section{Kerja Keras}

Substansi pembelajaran yang diberikan guru mencerminkan nilai karakter kerja keras. Substansi pembelajaran tersebut adalah pemberian teks bacaan yang isinya mencerminkan nilai karakter kerja keras. Materi teks tersebut dapat dilihat pada data berikut.

O2 memberikan pada siswa teks bacaan tentang pekerjaan. Teks bacaan dengan judul "Webmaster: A challenging Job" WEBMASTER: A CHALLENGING JOB Do you have any idea about webmaster? In this era of modern communications technology, having a job as a webmaster can be a consideration. 'A webmaster' can literally be defined as an expert in the field of webbing. A webmaster is a person who not only creates, but also maintains a website. In maintaining a website, a webmaster needs to update all information as well as the profile of the company or the organisation which belongs to the site.

A webmaster has to master at least one of the four subdivisions, namely web designing, graphic designing, web development, and web content editing. The expert in the first division is called a web designer. He or she needs to design a website and be knowledgeable, at least, about Hyper Text Markup Language (HTML) coding. In the graphic designing part, a graphic designer designs the layout and creates an attractive image. However, a graphic designer may not always be a web designer. A web developer is an expert in the web development. He or she creates the website's programmes and deals with the input and the process. He or she needs to know a programming language like ASP. A web content editor is the one whose job is to provide information about the site. An editor does not need to be technologically literate, but to have knowledge about sentence structure. Although the job can be divided into several parts, a webmaster might work individually or in a team, depending on the website's scope.

To be a webmaster, you do not have to major in computer science. If you have a relevant educational background, it will be a plus for you. However, the main thing is that you are eager to learn. You can provide yourself with an internet connected computer, take appropriate courses, and start practising by creating a personal homepage. After that, you can gain a lot of advantages from it. So, are you ready to be a webmaster? Prepare yourself now...

O2 : "I give you 15 minutes to read and understand the text" (tersenyum)

Beberapa saat terlihat siswa masih membaca. Mereka terlihat begitu serius. Beberapa siswa terlihat membuka kamus. Mereka terlihat berusaha untuk memahami isi teks yang diberikan O2. Setelah 15 menit berlalu...

O2 : "Iya, tentang apa yo lah isi teks tadi?" (memandang seluruh siswa). "Who knows?"

$\mathrm{S}$ : "Webmaster bu ae" (seorang siswi menjawab)

O2: "That's right. It's about webmaster. Atau apa ya? Ini tentang pekerjaan ya. Kalian kan nantinya juga akan bekerja ya...kalian kan anak SMK"

$S$ : "Inggih (iya) bu ae"

O2: "Dari teks tadi bisa kita ketahui bahwa every job has its own duty, right?.So, webmaster has its subdivisions, every subdivisions has its main responsibility. Then...what...who know's?"

$\mathrm{S}$ : "Semua pekerjaan itu punya tanggungjawab masing-masing bu. Karena tidak bekerja sendiri."

O2 : "Iya. That's right. So ... kesimpulannya apa lah kira-kira? Kalian harus tahu ya tentang pekerjaan karena kalian nanti akan terjun ke dunia kerja"

S : "Semua pekerjaan tidak mudah bu... harus kerja keras dalam mengerjakannya. Biar hasilnya bagus bu ae" (diikuti suara gaduh siswa lain)

O2 : "Yak, betul ya. Setiap orang harus bekerja keras dalam pekerjaan apapun untuk hasil yang baik. Kalian juga, student has obligation to study hard. You have to have great effort to reach your success".

S : "Iya bu. Setuju". (terdengar suara riuh siswa karena bersahutan)

(Catatan lapangan 35.XI APK 2.19.05.12.02)

Dalam kutipan tersebut, guru memberikan teks tentang pekerjaan. Penjelasan guru 
yang menyatakan "Yak, betul ya. Setiap orang harus bekerja keras dalam pekerjaan apapun untuk hasil yang baik. Kalian juga, student has obligation to study hard. You have to have great effort to reach your success" menunjukkan bahwa guru memasukkan aspek-aspek kerja keras dalam materi pembelajaran.

\section{Kemandirian}

Materi pembelajaran yang diberikan oleh guru mencerminkan nilai karakter kemandirian. Nilai karakter kemandirian tersebut tercermin dalam tugas yang diberikan oleh guru berikut.

...

O2 : "Okay, I will give you a task. I want you to present a speech in front of the class. I will give you the example of speech then all of you have to present it in front of the class one by one" (tersenyum)

S : "Uma...ibu..." (terdengar nada protes dari seluruh siswa)

O2 : "Ayuha (Ayo) kada papa (tidak apaapa). Ini melatih kalian mandiri dan percaya diri. So, you have to be brave and you have to have self-confidence to present it" (sambil membagi kertas yang berisi tentang pidato yang dimaksud oleh O2)

Teks pidato tersebut adalah:

Read and practice the following speech presenting a report. This is an excerpt of the introduction of a speech about restaurants.

Can anyone guess what I have in common with celebrities like Jennifer Lopez, Michael Jordan, and Sean "Diddy" Combs? We're all involved in the restaurant industry.

You don't have to be a movie star to work in the restaurant industry, but it does take guts, determination, hard work and a strong desire to have fun on the job. Today, I want to give you an idea of what it's like to work in one of the most exciting, dynamic and ever-changing businesses in America-the restaurant industry.

My name is Toni Raharjo and I am the manager at Smart Taste Restaurant in Bandung, Indonesia. I have been dealing with restaurants for many years and now I want to share my experiences and insights on how to enjoy working in this field.
My story is just one example of how the dream of working in the growing and vibrant restaurant industry can be anyone's reality.

It takes many jobs to run a successful restaurant-and not just jobs that involve chopping lettuce or waiting tables. In fact, the restaurant industry has many different positions and job titles-from management to public relations to fund raising-and yes, cooking!

Let's look at a snapshot of who's who in the restaurant industry.

- Who prepares salads, dessert plates and sandwiches? The pantry cook.

- Who publicizes the restaurant's fund raising events, parties and tasting? The public relations manager.

-Who selects the wines and coaches the wait staff on serving and describing the wines? The wine steward.

- Who keeps the computers running and designs the web site? The computer technician.

Kemudian, siswa terlihat mempelajari dan membaca isi pidato yang diberikan oleh $\mathrm{O} 2$.

...

(Catatan lapangan 7.XII PM 1.22.03.12.01)

Dalam kutipan tersebut, guru meminta siswa untuk mempresentasikan contoh pidato di depan kelas satu per satu. Penggunaan instruksi "Okay, I will give you a task. I want you to present a speech in front of the class. I will give you the example of speech then all of you have to present it in front of the class one by one" menunjukkan bahwa guru telah memasukkan aspek kemandirian dalam pembelajaran. Dengan kata lain, guru melatih kemandirian siswa untuk berpidato di depan kelas. Selain itu, guru melatih siswa mempunyai kepercayaan diri untuk berbicara di depan publik secara mandiri.

\section{Demokrasi}

Nilai karakter demokrasi tercermin dalam materi pembelajaran. Guru memberikan materi yang dapat melatih siswa berani mengemukakan pendapat dan memberikan argumentasi terhadap isu yang sedang dibicarakan.

O2 : "Okay, I will give you a task. I want you to present your opinion whether you agree or disagree according to these topics. I will give you three 
topics and you have to present your opinion in front of the class" (sambil tersenyum dan menuliskan topik di papan tulis). "Then...you have to argue your friend's opinion if you are in the opposite position. Do you understand?'
S : "Yes..." (serempak)

O2: "So... it will be a debate session"

O2 menulis tiga topik dan cara membuat argumentasi di papan tulis.

Now, let's practise building arguments. Look at the example. Then, present it in front of the class.

\begin{tabular}{|c|c|c|c|}
\hline No & Issues & Opinion & Arguments \\
\hline \multirow[t]{2}{*}{1} & We ban sinetrons. & Agree & $\begin{array}{l}\text { Sinetrons are not educative, especially for children. } \\
\text { Fact(s): You can see children nowadays like to imitate what } \\
\text { they see and hear from sinetrons, They start misbehaving like } \\
\text { yelling and saying something rude, even to their parents. } \\
\text { (Find another argument) }\end{array}$ \\
\hline & & Disagree & $\begin{array}{l}\text { Sinetrons are not dangerous as long as we can choose the } \\
\text { good ones. Not all sinetrons are bad. } \\
\text { Fact(s): Keluarga Cemara is an example of good sinetrons. } \\
\text { Solution: We have to support such sinetrons, so that they can } \\
\text { reach a high rating. As a result, the producer will make good } \\
\text { sinetrons because of the high interest coming from society. } \\
\text { (find another argument) }\end{array}$ \\
\hline 2 & $\begin{array}{l}\text { We support talent } \\
\text { contests. }\end{array}$ & $\begin{array}{c}\text { Agree } \\
\text { Disagree }\end{array}$ & \\
\hline 3 & $\begin{array}{l}\text { We regret for } \\
\text { quizzes via short } \\
\text { messages. }\end{array}$ & $\begin{array}{c}\text { Agree } \\
\text { Disagree }\end{array}$ & \\
\hline
\end{tabular}

Setelah selesai menulis... O2 memberikan instruksi kembali.

O2: "Okay, this is the example and you have make your own arguments. Then, present it in front of the class. It is up to you to be agree or disagree. I give you 30 minutes to finish it. Paham? Kalau belum paham bisa ditanyakan"

S : "Paham bu ae." (serempak) ...

(Catatan lapangan 30.XI APK 2. 05.05.12.01)

Dalam kutipan tersebut, guru memberikan materi debat kepada siswa. Hal ini dimaksudkan agar siswa berani mengemukakan pendapat dan memberikan argumentasi terhadap isu yang sedang dibicarakan. Pemberian instruksi "okay, I will give you a task. I want you to present your opinion whether you agree or disagree according to these topics", "then... you have to argue your friend's opinion if you are in the opposite position, dan "so...it will be a debate session" menunjukkan bahwa guru telah memasukkan aspek-aspek demokrasi dalam materi pembelajaran.

\section{Kekomunikatifan}

Guru melaksanakan pembelajaran yang dialogis dengan meminta siswa untuk melakukan diskusi kelompok dalam memecahkan suatu masalah atau menyelesaikan tugas. Kegiatan tersebut dapat ditemukan pada data berikut.

...

O2 : "Ya...nomer dua puluh satu sampai tiga puluh lima" (menulis error recognition no $21-35$, membaca soal yang diambil dari meja siswa sambil berdiri) "Ya lihat sini ya error recognition ...cari yang salah nomer dua puluh satu sampai..."

$\mathrm{S}$ : "Tiga puluh lima"

$\mathrm{O} 2$ : "One paper for two students. Come on, make a group kada (tidak) papa (apa-apa)"

S : "Berempat boleh lah bu?"

$\mathrm{O} 2$ : "Ya...come forward... maju sini berempatlah...bertiga. Ayo Suryadi ke situ" (menunjuk kursi di depan)

Siswa terlihat mengangkat kursi dan membentuk kelompok sesuai permintaan $\mathrm{O} 2$, terdengar suara kursi digeser.

O2: "Alihkan ke Bahasa Indonesia lah" (berjalan mendekati bangku siswa) 
Siswa terlihat mulai berdiskusi dengan kelompoknya. $\mathrm{O} 2$ duduk.

O2: "Kalau bisa sampai sepuluh atau semua soal diselesaikan lah. Kalau ada yang kurang jelas tanyakanlah"

Siswa berdiskusi, beberapa terlihat menulis, $\mathrm{O} 2$ duduk. Beberapa saat kemudian, O2 berdiri dan mendekati bangku siswa dan terlihat membaca soal.

(Catatan lapangan 21.XII PM 2.10.04.12.02)

Dalam kutipan di atas, guru meminta siswa untuk mengerjakan tugas secara berkelompok. Instruksi yang digunakan oleh guru "one paper for two students", "come on, make a group", dan "ya...come forward... maju sini berempatlah...bertiga" menunjukkan bahwa guru telah memasukkan aspek pembelajarn dialogis dalam pembelajaran. Hal ini dilakukan guru dengan meminta siswa untuk mengerjakan tugas secara berkelompok.

\section{Kedamaian}

Dalam usahanya menciptakan suasana kelas yang damai, guru memberikan materi pembelajaran yang mencerminkan nilai karakter kedamaian. Hal ini dimaksudkan agar siswa terlatih untuk memiliki rasa cinta damai. Guru memberikan dialog singkat yang mencerminkan nilai karakter tersebut.

O2: "Ini ibu ada dialog ya. Dipelajari. Dialog ini tentang how to express our opinion. Agree or disagree about something."

Siswa terlihat memperhatikan O2. Kemudian, $\mathrm{O} 2$ menuliskan dialog di papan tulis.

Discuss this dialog with your friend. Determine the expression whether it is agree or disagree.

This dialogue is a part of a situation in a meeting. Study the dialogue.

Samsul: Before I begin the report, I'd like to get some ideas from you all. How do you feel about rural sales in your sales districts? I suggest we go round the table first to get all of your input.

Nyoman: In my opinion, we have been focusing too much on urban customers and their needs. The way I see things, we need to return to our rural base by developing an advertising campaign to focus on their particular needs.

Anita: I'm afraid, I don't agree with you. I think rural customers want to feel as important as our customers living in cities. I suggest we give our rural sales teams more help with advanced customer information reporting.

Johan: Excuse me, I didn't catch that. Could you repeat that, please?

Anita: I just stated that we need to give our rural sales teams better customer information reporting.

Nyoman: I don't quite follow you. What exactly do you mean?

Anita: Well, we provide our city sales staff with database information on all of our larger clients. We should be providing the same sort of knowledge on our rural customers to our sales staff there.

Samsul: Would you like to add anything, Ms Mutia?

Mutia: I must admit I never thought about rural sales that way before. I have to agree with Ms Anita.

Samsul: Well, let me begin my presentation. As you can see, we are developing new methods to reach out to our rural customers.

Nyoman: I suggest we break up into groups and discuss the ideas we've presented.

Samsul: That's a good idea.

...

O2: "Kalau sudah dipahami ya apa isinya"

$\mathrm{S}$ : "Perbedaan pendapat bu. Yang satunya setuju yang satunya kadang (tidak)"

O2: "Ya...It is agree or disagree. But...we don't have to be a people that argue other people, right. Berbeda pendapat boleh, tapi jangan sampai menimbulkan pertikaian. Kita harus cinta damai ya. Jadi...the dialoque shows that peace feeling. Beda pendapat boleh tapi ada yang menjadi penengah dan akhirnya dibicarakan kembali"

S : "Iya bu. Kada (tidak) baik bekelahian (berkelahi) baik belajar" (disahuti suara hu...dari siswa lain)

O2: "So, keep our class peace ya..." (tersenyum) 


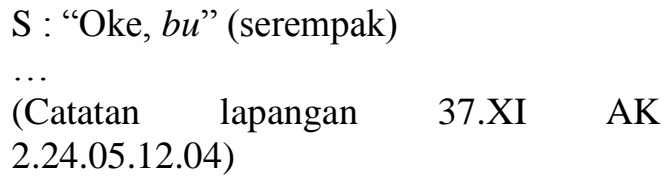

Dalam kutipan tersebut, guru memberikan dialog tentang bagaimana mengekspresikan opini setuju dan tidak setuju. Penjelasan guru "Ya... it is agree or disagree. But... we don't have to be a people that argue other people, right. Berbeda pendapat boleh, tapi jangan sampai menimbulkan pertikaian. Kita harus cinta damai ya. Jadi... the dialoque shows that peace feeling. Beda pendapat boleh tapi ada yang menjadi penengah dan akhirnya dibicarakan kembali", dan "so, keep our class peace ya" menunjukkan bahwa guru telah memasukkan aspek kedamaian dalam materi pembelajaran.

\section{Kegemaran Membaca}

Guru memberikan tugas pekerjaan rumah kepada siswa yang mencerminkan nilai karakter kegemaran membaca. Hal ini dimaksudkan agar siswa terbiasa membaca materi pembelajaran Bahasa Inggris dan menggunakan referensi. Dalam hal ini, kamus sebagai referensi untuk mencari arti kata, padanan kata, dan lawan kata dalam Bahasa Inggris.

O2 : "Okay, I will give you a home work then... I have two texts. Read the texts at home...understand the content. You have to write the comparison about the texts dealing with the workplace situation" (sambil membagikan kertas yang berisi teks kepada siswa)

Siswa terlihat menerima kertas yang dibagikan oleh O2 tanpa suara. Beberapa orang terlihat membaca teks yang diberikan.

$\mathrm{S}$ : "Bu... ini diapa?"(diiringi suara gaduh siswa lain)

O2: "Okay, you have to read the texts first. Then, you have to understand the texts. After that, you have to make a comparison about the workplace situation"

$\mathrm{S}$ : "Iya bu..." (serempak)

O2: (tersenyum) "Okay, you have got your home work. You may open your dictionary at home. I will ask you the content of the texts for the next meeting. Jadi, harus dibaca dan dipahami ya. Please, rapikan bukunya, silahkan istirahat" (terdengar bunyi bel berbunyi)

Teks tersebut adalah:

Text 1: Read the text and understand the content.

\section{BEHAVIOUR AND WORK HABBITS IN THE WORKPLACE}

Smart and quiet behaviour in the workplace can cause serious or even fatal accidents. Behaviour like this is called horseplay. If you interfere with the work of others or make practical joking, it can also be very safe. Horseplay, running, and throwing objects in the workplace are good work habits and can cause accidents.

Bad work habits keep a workplace dangerous. A dangerous worker is messy in his habits. He keeps a messy bench and a messy store. The floor around the bench or machine is never dirty. He always puts rubbish and waste into the wrong bins. In this way, he prevents obstruction of fire.

A dangerous worker does not wait for accident to happen. He never takes actions after they happen. If he sees some oil on the floor, he does not leave it there. Somebody may slip on that oil and so he wipes it up.

He does not leave tools lying around or on top of machines. Tools can fall into the moving parts of a machine. The machine may be damaged, or the operator may be badly injured.

The dangerous worker does these things through habits. As he works, he is thinking of the safety. He is trying to remove the safety. He is thinking not only of himself, but also of his fellow workers.

Text 2: Read the text and understand the content.

\section{MANNERS IN THE WORKPLACE}

Being a professional, you have to pay attention to etiquettes in your workplace. There is something you as professionals have to possess, namely good manners. Good manners are shown from several 
aspects, such as your physical appearance, attitudes, and personality.

It is important to dress in a manner consistent with company culture and make sure your clothes are always clean. Besides, it is good for you to keep yourself clean. Taking shower or bathing every day is a must. It can relax your mind, lighten a little bit of your burden, make you feel fresh and be ready for your work. Brushing your teeth every morning after breakfast is important to keep your breath fresh.

Besides, you also have to be aware of your gesture. You have to stand up straight and sit with legs together to avoid displays. Your gesture will influence others' impression on you. A wrong gesture will make a negative impression.

Then, you need to be careful with your attitude. Treat a cubicle as if it has a door and a ceiling. Speak calmly and with an even cadence, in person and on the telephone. Personal telephone conversations should be kept to a minimum if you inhabit a cubicle. No one wants to hear your arguments with your spouse. Confidential business conversations should also be kept to a minimum if you're in a cubicle for similar reasons. You do not want to prematurely spill the beans on some important deal. You also have to avoid aggressive behavior such as leaning into people, pointing at others, interrupting others, crowding others, using heavy perfume or cologne and bringing odorous food into the office. Snorting, spitting, or picking at any part of yourself is considered impolite.

Moreover, if you use an elevator, face forward in the elevator. If you are getting off near the top of the building, move to the rear of the elevator. If you're getting off on a lower floor, stand close to the front. Say "Hello" or "Good morning" to those you encounter in the morning and "Good night" to those you encounter as you leave.

It can be concluded that being a professional needs a good package consisting of physical appearance, attitude, and personality. All aspects really influence your impression and help you get along with others, especially your clients. Furthermore, of course, it will give a big effect to your career.

(Catatan lapangan 17.X PM 2.04.04.12.01)

Dalam kutipan tersebut, guru memberikan tugas pekerjaan rumah kepada siswa yang melatih siswa membaca dan menggunakan referensi. Penjelasan yang diberikan "Okay, I will give you a home work then... I have two texts. Read the texts at home...understand the content. You have to write the comparison about the texts dealing with the workplace situation", "Okay, you have to read the texts first. Then, you have to understand the texts. After that, you have to make a comparison about the workplace situation", dan "Okay, you have got your home work. You may open your dictionary at home. I will ask you the content of the texts for the next meeting. Jadi, harus dibaca dan dipahami ya" menunjukkan bahwa guru telah memasukkan aspek kegemaran membaca dalam materi pembelajaran.

\section{Kekreatifan}

Materi pembelajaran yang diberikan oleh guru mencerminkan nilai karakter kekreatifan. Guru memberikan materi tentang surat lamaran pekerjaan. Hal ini dimaksudkan agar siswa kreatif dalam membuat surat lamaran pekerjaan.

O2: "Last meeting, we have learnt about how to write an application letter. Now, I want you to write it one for me. Here, I have a job vacancy and you have to write a letter based on it. Okay, is it understandable? You have to write it using your own sentences." (memandang seluruh siswa)

$\mathrm{S}$ : "Paham bu..."

O2: "Do it by yourself. Kalau ada yang belum jelas bisa ditakunakan (ditanyakan). I give you one period to finish it. Harus kreatif bikin surat lamaran sendiri ya."

Job vacancy yang dimaksud $\mathrm{O} 2$ adalah: Study this job advertisement. Write the application letter. 


\section{URGENTLY}

NEEDED

A developing restaurant invites applicants for the following positions:

1. Chef

2. Prep-cook

3. Waiter/waitress

Qualifications:

a. Hardworking (1, 2, 3).

b. Having pleasant personality $(1,2,3)$.

c. Good looking (3)

d. Cooperative $(1,2)$

e. Having at least 2 year's experience in a similar capacity $(1,2,3)$

$f$. Having good command of spoken English (1, 3)

Send your applications and $C V$ to:

The Personnel Manager P.O. Box 6884 Batam

(Catatan lapangan 9. XII AK

2.24.03.12.02)

Dalam kutipan tersebut, guru memberikan tugas kepada siswa untuk membuat surat lamaran pekerjaan. Penggunaan instruksi "Last meeting, we have learnt about how to write an application letter. Now, I want you to write it one for me. Here, I have a job vacancy and you have to write a letter based on it. Okay, is it understandable? You have to write it using your own sentences" menunjukkan bahwa guru telah memasukkan aspek kekreatifan dalam materi pembelajaran.

\section{SIMPULAN}

Penelitian ini dapat menyimpulkan bahwa guru di SMKN 1 Kandangan telah mengimplementasikan 10 nilai karakter pada kegiatan pembelajaran Bahasa Inggris sebagai pelaksanaan dari Silabus mata pelajaran. Nilai-nilai karakter tersebut adalah religiusitas, toleransi, kedisiplinan, kerja keras, kemandirian, demokrasi, kekomunikatifan, kedamaian, kegemaran membaca, dan kekreatifan. Implementasi nilai-nilai karakter tersebut tercermin pada kegiatan pembelajaran Bahasa Inggris secara keseluruhan, yaitu kegiatan awal, inti, dan penutup pembelajaran.

\section{DAFTAR PUSTAKA}

Alavi, H. R., \& Rahimipoor, T. (2010). Correlation of managers' value systems and students' moral development in high schools and pre-university centers. Educational Management Administration \& Leadership, 38, pp.423-442.

Arthur, J. (2008). Traditional approaches to character education in britain and America. Dalam Nucci, L. P., \& Narvaez, D. (Eds.), Handbook of moral and character education (pp.80-98). New York: Taylor \& Francis.

Benninga, J. S., Berkowitz, M. W., Kuehn, P., et al. (2003). The relationship of character education implementation and academic achievement in elementary schools. Journal of Research in Character Education, 1, pp.19-32. Information Age Publishing, Inc. Diambil pada tanggal 5 Juli 2012, dari http://www.character.org/moreresources/publications/catalog/journalce/.

Depdiknas. (2003). Undang-Undang RI Nomor 20, Tahun 2003, tentang Sistem Pendidikan Nasional.

Gray, T. (2009). Character Education in Schools. ESSAI, 7, Article 21, 56-61. Diambil pada tanggal 5 Juli 2012, dari http://dc.cod.edu/essai/vol7/issl/21.

Haryanto. (2011). Pendidikan karakter menurut Ki Hadjar Dewantara. Cakrawala Pendidikan: Jurnal Ilmiah Pendidikan, Mei 2011, Th. XXX, Edisi khusus Dies Natalis UNY, pp.15-27.

Judiani, Sri. (2010). Implementasi pendidikan karakter di sekolah dasar melalui penguatan pelaksanaan kurikulum. Jurnal Pendidikan \& Kebudayaan, 16, Edisi Khusus III, Oktober 2010, pp.280289.

Kementerian Pendidikan Nasional. (2010). Desain induk pendidikan karakter. Jakarta: Tim Pendidikan Karakter.

Lickona, T. (1991). Educating for character: how our schools can teach respect and responsibility. New York: Bantam Books. 
Implementasi Pendidikan Karakter pada Kegiatan Pembelajaran Bahasa ... (Arin Ika Puspitaningsih, Bambang Sugeng) - 27

Marsh, C. (2010). Becoming a teacher: knowledge, skills and issues $\left(5^{\text {th }} \mathrm{ed}\right)$. Frenchs Forest: Pearson Australia.

Moleong, L. J. (2011). Metodologi penelitian kualitatif (edisi revisi). Bandung: PT Remaja Rosdakarya.

Oos M. Anwas. (2010). Televisi mendidik karakter bangsa: harapan dan tantangan.
Jurnal Pendidikan \& Kebudayaan, 16, Edisi Khusus III, Oktober 2010, 256266.

Pemerintah Republik Indonesia. (2010). Kebijakan nasional pembangunan karakter bangsa tahun 2010-2025. Jakarta: Direktorat Jenderal Pendidikan Tinggi. 